ック・キャスト4 $: 2 \mathrm{~mm}$ 直径の塩化ビニールの玉の入 った袋状のもので, 真空ポンプで袋内の空気を抜くこ とにより固定させる，多点固定具 ${ }^{4}$.22!：額，耳，顎等 を機械的に抑えることによって固定する，石膏やギブ ス材を用いた固定具23：整形外科用のギブスを用いた り，石亳を用いてシェルを作成．放射線治療用に開発 されたシェル：比較的低温で可逆的に変化するシェル
が市販されている。

体動の抑制，特にシェルの詳細は別項に譲る。

\section{的 辞}

発表の機会を与えて頂いた川上壽昭学会長，中村 修 大会長，並びに平林久枝分科会長に感謝いたします。

\title{
参考文献
}

1) ICRU Report 24 (1976): Determination of absorbed dose in a patient irradiated by beam of $\mathrm{X}$ or Gamma rays.

2) 大川智彦, 池田道雄：臨床腫瘍学からみたがんの放射線治 療, 医学書院, (1983)

3）尾内能夫：放射線基礎医学 III，日本出版サービス，(1984）

4）木村千秋：治療計画(治療技術委員会 マニュアル作裴班). 日放技学誌，37(3),344-371,(1981).

5) 熊谷孝三, 他：㬋頭癌の放射線治療. 放射線治療研究会雑 誌, 8(1), 63-76,(1994).

6) Ellis F and Miller : Use of wedge filter in X-ray therapy. J. Radiol., 17, 90-94, (1944).

7) 勝田稔三，他：早期声門部癌の放射線治療におけるウエッ ジ・フィルターの検討。 日放技学誌, 41(7)，1048-1053, (1985).

8) 保科正夫, 他：コバルト外照射に於ける組織欠損と斜入射 の補償。日放技学誌，36(5), 547-554, (1980).

9) 小口 宏, 宮沢正則, 他: 補償フィルターの作成装置の開 発. 第43回総会研究発表抄録 \#446-\#447, (1987).

10）木村千明, 他： $6 \mathrm{MV} \cdot \mathrm{X}$ 線による上顎澏原体照射の基礎実 験。日放技学誌, 30(4), 343-347, (1974).

11) paradelo JC, Ucmakli A, et al.: MidSagital Plane Dosimetry In Patients With Extensive Head And Neck Malignancy. Int. J. Radiat. Oncol. Biol. Phys., 7 (1), 115-120, (1981).

12) Fletcher G: Textbook of Radiotherapy. Philadelphia, Lea \& Febiger, p.276-287, (1973).

13) Fletcher G, et al.: Textbook of Radiotherapy (Third Edition). Philadelphia, Lea \& Febiger, p.1-102, (1980).

14）松本光弘，他：高エネルギーX線治療におけるMatch-Line Wedgeを用いた照射野つなぎ合わせ技術の検討，日放技学 誌, 43(5), 601-609, (1987).

15) Wood RG: Computer in radiotherapy-physical aspects. Butterworths, London, (1974).

16）松田忠義編：放射線治療とCT. 秀潤社 (1982).

17) 尾内能夫：放射楾治療機器の進歩. 東芝メディカル レビ 工一, \#12(1982)-\#19(1984).

18) 工藤牧夫, 他：放射線治療における照射位置の再現性に関 する唡討。 日放技学誌，33(3)，250-255，(1977).

19) AAPM Report \#13: Physical aspects of Radiation Therapy. p.34-37, (1984).

20) Grimm F, Gillin, et al.: Electron beam port films. Medical Dosimetry. 14, 31-33, (1987).

21）川越康充, 松本光弘, 他: オンライン・リアルタイム・ポ ータルイメージング(THERAVIEW)を用いたSet up errorの 発生頻度の解析．第43回総会研究発表抄録 \#79, (1995)。

22) 水谷武雄, 植田俊男 : 放射線治療用頭部固定具の試作と検 討. 日放技学誌，33(3)，245-249，(1977).

23）山口 恵, 渡辺良晴, 他：新しいシェル素材の使用経娩. 第43回棇会研究発表抄録 \#99,(1984).

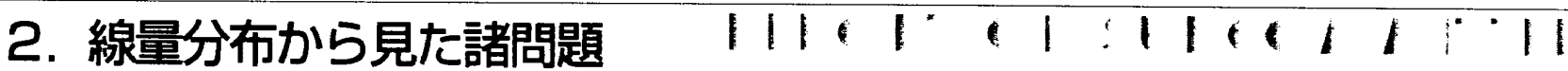 \\ 小口宏 \\ 信州大学医学部附属病院}

\section{1. はじめに}

頭頸部癌の治療は，機能と形態を保存することが重 視されるため, 放射線治療が第一の治療法として選択 されることが多い．特に喉頭や舌などの早期癌は局所 制御率が高く根治照射の対象となり，また咽頭部癌な どは切除範囲が広くなるため手術適応とならない場合 が多く，放射線治療に対する期待が大きい．

一方，放射線治療の局所制御率は線量に依存し高線 量ほど高い制御率が期待できるが，眼球，春髄，口 腔, 舌など多くの器官で構成される頭頸部領域の治療 は，正常組織の耐容線量を考慮することが重要な課題 となる。照射技術から見れば，照射容積に含まれる Clinical target volume (CTV) とOrgans at risk'の線量 を把握することが必要となる。また頭頸部は体輪郭が 不規則で, 各器官の形態や解剖学的位置関係も複雑と なるため，最適な線量分布となる照射術式の選択や， 治療補助具の使用が求められる。

\section{2. 照射国のつなぎ合わせ}

上咽頭腫瘍などではまず拡大照射として頸部，鎖 骨上窩リンパ節を含むように頭蓋底から鎖骨上䆟ま でを50Gy程度照射し，次に原発巣とRuviereリンパ 節に対し追加照射(Boost therapy)を15-20Gy行う。 拡大照射の範囲は広いため, 側方対向二門照射の頸 部 (Neck) と前一門照射の鎖骨上窩(SC)に分割して治 療する (Fig.1 (a))が，この隣り合った照射野のつなぎ 目の線量分布が問題となる。

代表的な照射野のつなぎ合わせ方法は次の 5 種類で ある。(1)Field separation法”は任意の深さで亘いの照 射野縁が交差するようアイソセンタ一間のシフト量を 計算で求めるが，交差点以外では線量分布が大きく変 化してしまう. (2)Angling beams away法 ${ }^{3}$ は基準とな る照射野のビーム縁に他の照射野のビーム縁が一致す るようコリメータや治療寝台の角度を調整する方法で ある，互いの半影を重㸚合わせる方法であるが，角度 
設定や接合面の再現性が難しい。3Field junction wedge法+.5: は，接合する照射野縁 の半影を特殊なフィルタで数 $\mathrm{cm}$ の幅に広 げる方法で，(1)に比べ照射野間隔のシフト エラーに対する線量分布の変化は少なくな る.しかしフィル夕の作製や位置合わせの 煩雑さがある. (4Half beam block法6は照 射野の半分を遮蔽し，半影の少ない照射野 同士を接合させるものである。深さにより 線量分布が変化することはないが，1 $\mathrm{mm} の$ セパレーションエラで10-20\%の線量エラが 発生する?ため毎回のセットアップ精度が 問題となる。

いずれにしろ患者セットアップの再現性 には限界があるため，治療期間内に数回の 接合面の移動を5Shifting field法により行 い, 線量分布の乱机を分散させる事が大切 である。

ファントム内のアイソセンタを含むコロ ナル面の線量分布をFig.1 (b) からFig.1 (f) に示す。また各線量分布の最大線量，最 低線量をTableに示す。

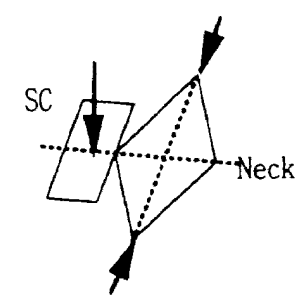

(a)

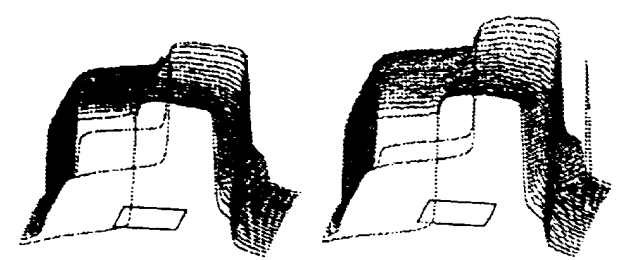

(d) (b)

(e)

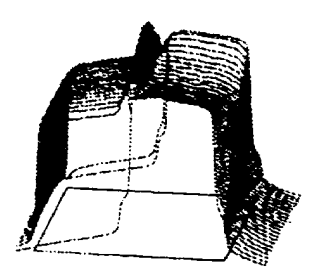

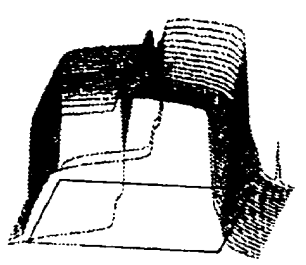

(c)

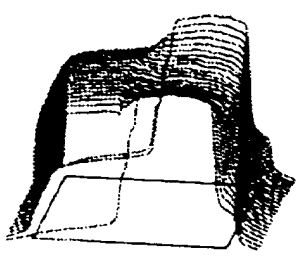

(f)
Fig. 1 Dose distribution of various techniques used for field matching. Adjacent field size : SC field is $20 \times 10 \mathrm{~cm}$ and Neck field is $10 \times 10 \mathrm{~cm}$. a : Schematic representation of nasopharynx treatment.

$b$ : Field adjusted at the skin surface.

c : Field separated at the skin surface.

d: Angling beams away from each other beams.

e : Half beam technique.

$f$ : Half beam technique with the shifting method.

\section{3. 照射術式}

追加照射や小容積の腫瘍に対しては，線量を原発巣 に集中させ周囲の正常組織の耐容線量を考慮した照射 術式の選択が重要となる。多門照射や回転照射を用 い，線質や線種を組み合わせたり線量ウエイトを変え るなど，細かな治療計画が必要となる，原体照射は大 变有効な手段であるが, 頭頸部領域はターゲットが比 較的小さく周囲との境界も複雑であるため, 三次元多 門照射法も重要な術式となるであろう。

このような複雑な設定にはCT画像を用いな治療計画 が必要で, 特にBeam's eye view (BEV)8を用いたアプ ローチは大変便利である。また，三次元の線量分布を 解析するッールとしてはDose volume histogram (DVH) ’があり，照射法の比較検討が客観的に行える。

\section{4. 線息分布計算・不均票補正}

頭頸部領域には空洞や骨などの不均質な構造を複雑 に有するため, 線量分布計算には不均質補正が必要と なる，不均質輪郭内の密度を代表的な值で補正する(1 Bulk inhomogeneity法とCT画像の各画素のCT值を利 用するPixel-by-pixel法がある。(1)はフィルムなどの CT值情報を持たないメディアを利用する場合に有用 であるが, 不均質部の抽出とその密度の推定が難し い. (2)はCT值より自動的に補正する方法で，CT装置 や撮影条件ごとのCT值一電子密度変換のテーブルが 必要となる。どちらの補正方法でも計算結果に大きな 差は無く, 計算アルゴリズムの精度以下であるとした 報告10があるが，頭頸部では不均質部が複雑であるた めPixel-by-pixel法が適していると考える。ただし，ア 一チファクトのある画像は注意が必要である。特にメ
タルアーチファクトはCT值が大きく変化しているた めPixel-by-Pixel法を用いてはならない.またCT值一 電子密度変換のテーブルはCT装置や撮影条件により 変化するため, 使用環境で測定したデータが必要とな る(Fig.2).

枕や患者抑制補助具などの外部輪郭が入射線束内に ある場合，その補正も忘れてはならない。

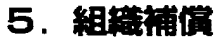

頭頸部では患者外輪郭の変化量が多く, 結果として 線量分布の不均一が発生する。頸部側方対向照射の場 合, 頸部と頼部の体厚幅は3-7cmもの差があり, これ により10\%を超えるhot spotが見られ，またIrradiated volume内の線量分布も輪郭形状や不均質の影響で複雑 に変化する，咽頭腫瘍の場合では，アイソセンタ一面 は実効厚の变化が少ないため 5 \%以内の線量であるが (Fig.3)，軸外-40mmの頸部では補償フィルタが無い

Table Maximum and minimum doses of various techniques used for field matching

\begin{tabular}{l|cc}
\hline & $\begin{array}{c}\text { Minimum dose } \\
(\%)\end{array}$ & $\begin{array}{c}\text { Maximum dose } \\
(\%)\end{array}$ \\
\hline Field separation *1 & 80 & 112 \\
Field separation *2 & 100 & 140 \\
Angling beams away & 100 & 111 \\
Half beam & 95 & 103 \\
Half beam *3 & 96 & 102 \\
\hline
\end{tabular}

*1) Field separated at the skin surface.

*2 Field separated at $5 \mathrm{~cm}$ depth.

*3) with the shifting method. 


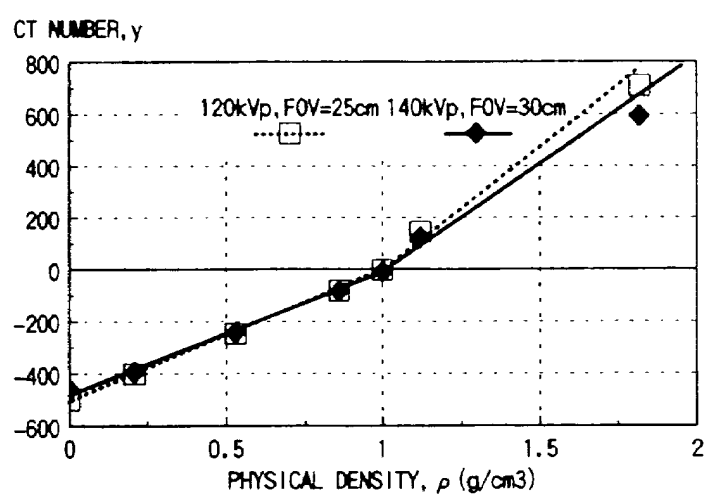

Fig. 2 Typical calibration curve for a CT scanner relating CT number to physical density.

Solid line: $140 \mathrm{kVp}, \mathrm{FOV}=30 \mathrm{~cm}$.

Dashed line: $120 \mathrm{kVp}, F O V=25 \mathrm{~cm}$.

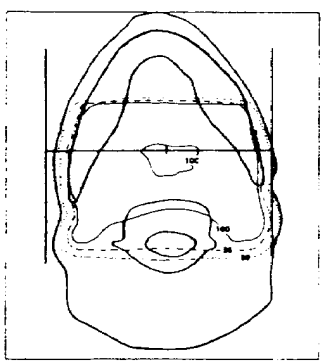

(a)

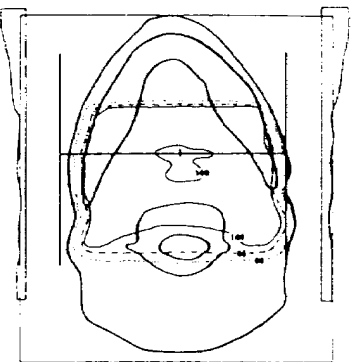

(b)
Fig. 3 Isodose distributions calculated at the central axis. a : without compensating filter.

$b$ : with compensating filter.

off axis plane (plus $40 \mathrm{~mm}$ level)

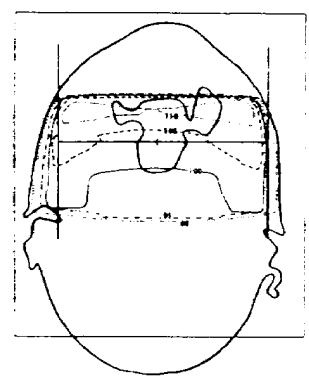

(a)

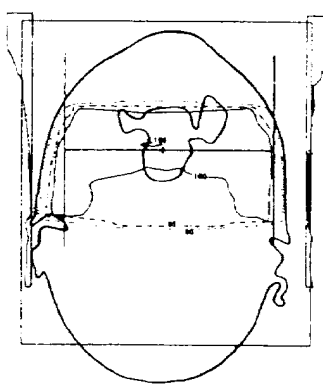

(b) off axis plane (minus $40 \mathrm{~mm}$ level).

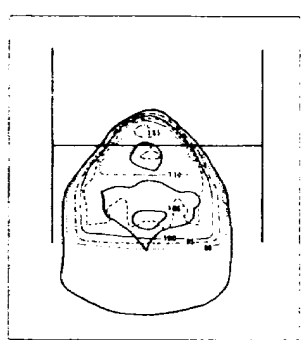

(a)

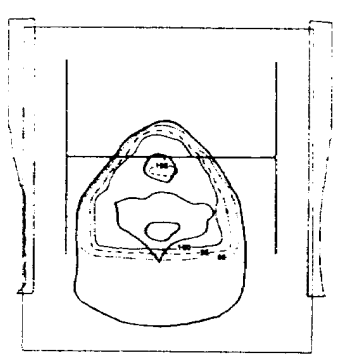

(b)
Fig. 4 Isodose distributions calculated at off axis plane. a: without compensating filter.

$\mathrm{b}$ : with compensating filter.

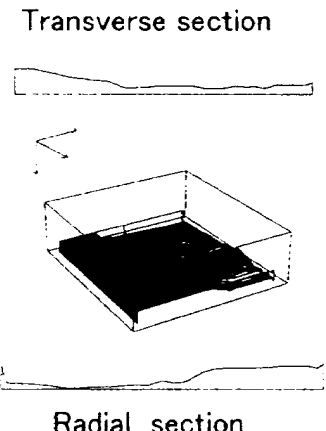

(a)

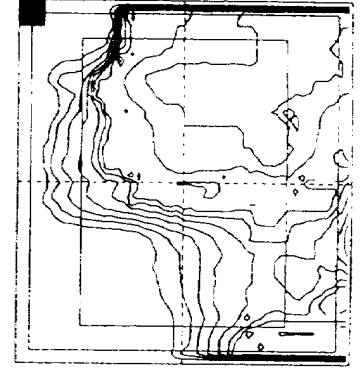

(b)
Fig. 5 Typical compensating filter for neck treatment using lateral field technique.

a: Bird's eye view

$b:$ Contour map.

場含 $116 \%$ も のhot spotが生じている(Fig.4). Planning target volume (PTV)内の線量変化は+7から-5\%の範囲 肉にすべきであるとの報告りあり，この線量分 有は好ましくない.

組織補償フィルタはこのような場合の補償に適 して扒り， off-axis面も芌め $\pm 5 \%$ 以内の線量幅に補 償することができる。

ここで使用した補償フィルタ(Fig.5)はCT画像を 用いた兰次元フィルタで， NC旋盤で鋳型を加工 し，補償材質に鉛粘士を用いたものであるい。

補償フィルタ作製に゙はロッドを使用して幾何学 的に外輪郭を取得する方法やに，アクリル樹脂プ レートを補償材としたものいなど多くの報告があ るが，いず扎も臨床で使用するには多くの時間と 手間が必要となる。しかし，一門照射や対向二門 のような単純な照射法の場合，補償フィル夕は線 量分布の改善に大変有効である。

\section{6. まとめ}

放射楾治療では線量の時間的配分と空間的分布 のコントロールが重要であるが，患者個々の治療 では高線量域をPTVに限りなく近づける治療計画 を行うことが重要な作業となる，治療計画は，照 射の再現性や線量測定などの諸問題と等しい重み の課題を負っており，特に頭䁰部領域は形態的， 解剖学的，また腫瘍学的に複雑な領域であるた め,さまざまなテクニックが要求される。

頭頸部の器官は左右対称または中心部に存在す るため，対向二門照射法が一般的となっている。 しかし局所制御の向上には高線量の投与が，また 患者のQuality of lifeのためにはより小さく且つ 十分なCTVが求めら机て括り，近い将来には三次 元多門照射の比重が増すものと考えられる。頭頸 部領域の今後の課題は三次元の治療計画をベース とした新しい照射プロトコルを確立することであ ろう。 
参考文献

1) ICRU: Prescribing, Recording, and Reporting Photon Beam Therapy, ICRU report 50, Maryland, (1993).

2) Keys R, Grigsby PW: Gapping fields on sloping surfaces., Int. J. Radiat. Oncol. Biol. Phys., 18, 1183, (1990).

3) Faiz MK: The Physics of Radiation Therapy, Wil-liams \& Wilkins, Maryland, (1992).

4) Armstrong DI, Tait $J$ : The matching of adjacent fields in radiotherapy., Radiology, 108, 419, (1973).

5) 松本光弘, 菊池利邦, 伊藤慎弥, 他: 照射野繋き目線量分 布の均一化の検討(Matching Wedge法), 第40回総会抄録, 208, (1984).

6) Chang TC, Culbert H, Whman B, et al.: The half field technique of radiation therapy for the cancers of head and neck., Int. J. Radiat. Oncol. Biol. Phys., 5, 1899, (1979).

7) Bukovitz AG, Deutsch M, Slayton R: Orthogonal fields: Variation in dose vs. gap size for treatment of the central nervous system., Radiology, 126, 795, (1978).
8) Tepper JE, Shank B: Three-dimensional display in Planning radiation therapy: a clinical perspective., Int. J. Radiat. Oncol. Biol. Phys., 21, 79-89, (1991).

9) Kessler ML, Pitluck S, Petti P, et al.: Integration of multimodality imaging data for radiotherapy treatment planning., Int. J. Radiat. Oncol. Biol. Phys., 21, 1653-1667, (1991).

10) Prasad SC, Glasgow GP, Purdy JA: Dosimetric evaluation of a computed tomograpy treatment system., Radiology, 130, 777-781, (1979).

11) 小口 宏, 宮沢正則, 竹村克人: 補償フィル夕作製装置の 開発 (その 1) 開発目的と現況報告, 第43回総会抄録, 1291, (1987).

12) 保科正夫, 後藤 功：コバルト照射に於ける組織欠損と斜 入射の補償. 日放技学誌，36, 547，(1980).

13）磯辺義秀，尾崎 新：CT画像を利用した放射線治療計画の 基礎的研究-4MV X線の外照射法への適用. 日放技学誌, 39, 140, (1985).

\section{3. 固定方法の違いによる誤差のデータ解析 CE SE C CAMAN}

\section{1. はじめに}

当院における透明のプラスチック・マスク(以下シェ ル)の使用は, 1979年に北海道大学より教授頂き, 現在 まで続いている。しかし，患者の状態などにより，頭 頸部の全症例にシェルを適応することが困難なのが現 状である。 また，固定時に用いる補助具も1979年から 1990年までは発砲スチロール製のドッグディッシュタイ プを用い，1990年以後はへッドレストタイプを使用して きた(Fig.1)。これらの固定方法による再現性の違いを 解析することは, 日常の照射位置設定の誤差要因の分 析，また，再現性を維持する上でのデー夕に基づいた指 標の取得の可能性からみて意義があると考え検討し た. そして，この指標值が照射位置の再現性を維持して いく上での，その施設の管理レベルになると考える.

\section{2. 方 法}

固定方法を(1)ドッグディッシュ，(2)シェルとドッグ ディッシュ,(3)ヘッドレスト, (4)シェルとヘッド レストの 4 グループに分け, シミュレー夕写真と ライナックグラフィーを照合することにより, 変位量を求めた。 その变位量は両者の写真に解 剖学的に確認できる共通のランドマーク(点)を 設定し, その座標值からX軸 (左右方向), $\mathrm{Y}$ 軸 (頭足方向), Z軸(前後方向)の三つの軸方向で求 めた。

この変位量が示す䛊差は, 治療計画と実際の 照射という相の違いにより発生する誤差(系統誤 差) と照射業務が反復作業であることから発生す る䛊差(偶然誤差)を含んでいるということを前 提として，平均值の差の検定と等分散検定によ る統計的な解析を行った。

\section{3. 結 果}

固定方法の異なる 4 つのグループの正面，及び，側 面の写真から得られた変位量の散布図をFig.2 とFig.3 に示す。図中のバーは両軸の標準偏差を表し，その交 点を中心とした楕円はデータ分布の $95 \%$ の信頼区間を 表している. 収集データの大半は，これらの楕円の中 に分散している。

\section{3-1 系統誤差について}

正面，及び，側面の写真から得られたそれぞれの散 布図に見られる棈円中心の座標值は，Table 1に示すよ うに，固定方法に関係なく楕円中心座標は，正面でX 軸が $\pm 0.5 \mathrm{~mm}$ 以下，Y軸が $\pm 0.2 \mathrm{~mm}$ 以下，また，側面に おいてもZ軸が $\pm 0.6 \mathrm{~mm}$ 以下, $\mathrm{Y}$ 軸が $\pm 0.2 \mathrm{~mm}$ 以下とな り，ほぼ原点 $(0,0)$ を心とした分散となった。この ように，固定方法に関わらす9 $95 \%$ 信頼区間を示す楕円 中心が原点近傍を中心として分散していることは系統 誤差の存在が無視できることが示唆される。これは，

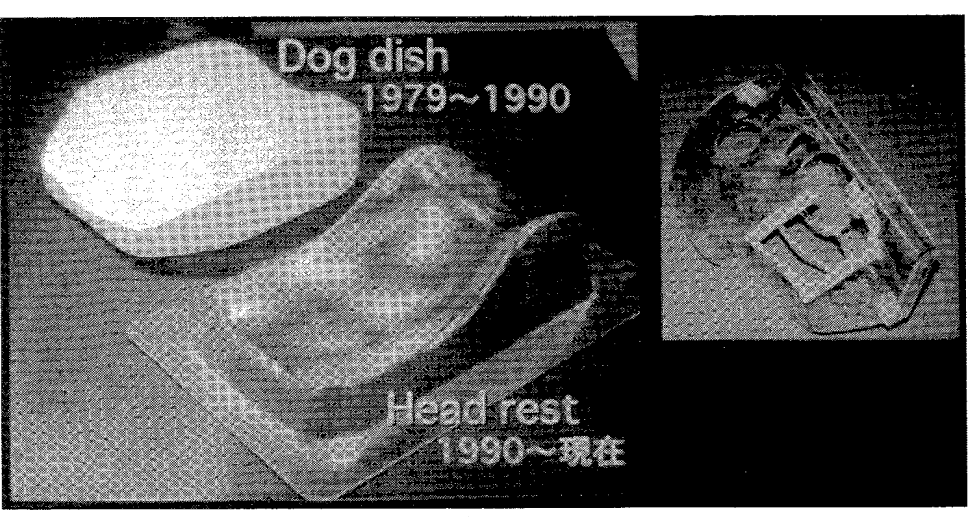

Fig. 1 Photography of dog dish used and from 1979 to 1990 and head rest used from 1990.

The right side panel is plastic mask (shell) used currently. 